McCann, Leonard Albert. Doctrine of the Void. The Doctrine of the Void as Propounded by St. John of the Cross in his Major Prose Works and as Viewed in the Light of Thomistic Principles. Thesis. Toronto: Basilian Press, 1956. 146 p. \$2.75.

*Miller, Oscar W. The Kantian ThingIn-Itself or the Creative Mind. New York: The Philosophical Library, 1956. xix, 142 p. $\$ 3.75$.

Norwood, Frederick Abbot. Development of Modem Christianity Since 1500. Nashville: Abington, 1956. 256 p. $\$ 3.75$.

Roth, Leon. Spinoza. New York: Barnes \& Noble, I955. 250 p. \$2.75. (Also,

NEW YORK UNIVERSITY
London: G. Allen. 12/6).

*Sykes, Norman. Old Priest and Neu Presbyter. Episcopacy and Presbyter. ianism since the Reformation with especial relation to the Churches of Eng. land and Scotland. (The Gunning Lectures, U of Edinburgh, 1953-54, and the Edward Cadbury Lectures, $U$ of Birmingham, 1954-55). New York Cambridge U Press, 1956. viii, $266 \mathrm{p}$ $\$ 5$.

Treinen, Hans. Studien zur Idee der Gemeinschaft bei Erasmus von Rotterdar: und zu ihrer Stellung in der Entwickluns des humanistischen Universalismus. Saarlouis: (Fontaine), 1955. 224 p. $840 \mathrm{f}$.

Robert E. Taylor

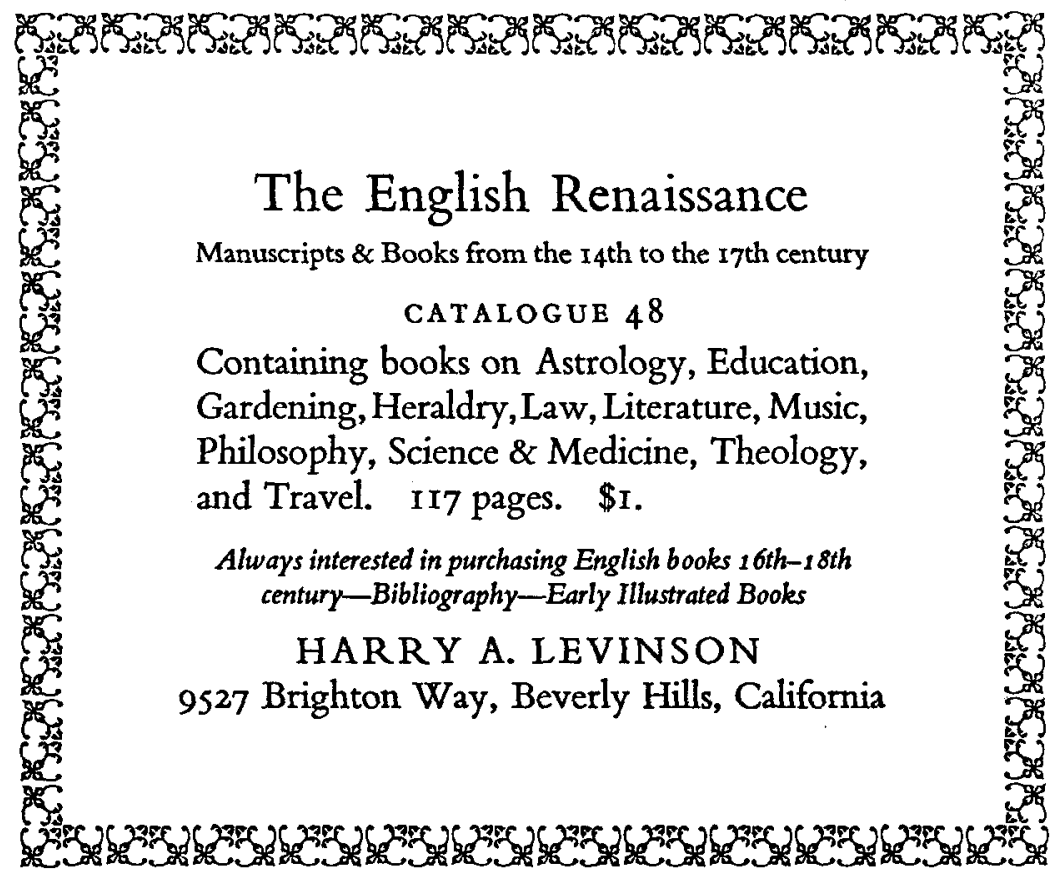

$[130]$ 
c Here at last is a book on the Renaissance which is not disfigured by purple passages and a grandiloquent and, in terms of contemporary thought, slightly suspect moral tone. Here instead is a historian's matching of fact and theory in a fusion of imaginative scholarship and strict historical impartiality. Carefully, shrewdly, and succinctly the relevant facts are weighed, sifted and the conclusions, which they prompt, carefully drawn with an observant eye on the relevant sources." - New Statesman \& Nation

\section{"A Ater reading this book with mounting} excitement, I do not think it possible to praise it too highly. Mr. Mattingly possesses so many and so varied gifts as an historian ... he brings to the history of Europe from the fifteenth to the seventeenth century a remarkable freshness of vision that carries conviction. Ten of his pages teach more about the growth, nature and decay of human institutions in the wayward hands of men than ten volumes of Toynbee. This is history as it should be written." - The Spectator

\section{RENAISSA NCE DIPLOMACY Garrett Mattingly}




\title{
The Classics
}

\section{and Renaissance Thought}

\author{
bY PAUL OSKAR KRISTEIIER
}

An illuminating analysis of the whole range of Renaissance thought in which the Renaissance is shown, not as a sharp break with tradition, but rather as a very natural continuation and transformation of what had come before. In four chapters, devoted to the Humanist movement, the Aristotelian tradition, Renaissarice Platonism, and paganism and Christianity, Professor Kristeller describes the influence of classical antiquity upon the thought of the Renaissance period. He describes the Renaissance as an age primarily concerned with the study and imitation of Greek and Latin literature, particularly Plato and Aristotle. In the last section the author shows that, while secular interests increased, religious thought and literature continued without interruption. This thought-provoking book draws a rough but comprehensive map of Renaissance learning and suggests a system of orientation in which each thinker and each philosophical idea may eventually be assigned to its proper place. The Martin Classical Lectures, 15. \$2.50

Through your bookseller, or from

HARVARD UNIVERSITY PRESS

CAMBRIDGE 38 , MASSACHUSETTS 